\title{
Straight by Day, Swingers by Night: Re-reading Daniel Bell on Capitalism and its Culture
} Jefferson Pooley

Daniel Bell's landmark Cultural Contradictions of Capitalism (1976) remains, 30 years later, the entry point to the rich literature on America's twentieth-century culture of selffulfillment. After reconstructing the book's argument with reference to Max Weber's account of modernity, this article challenges Bell's claim that Modernist culture and certain tendencies in capitalism threaten the social order. Capitalism and its culture are deeply symbiotic, and draw upon the same antinomian logic. Dionysus is welcomed with enthusiasm into the boardroom, mainly because apocalyptic moods and anti-rational modes of behavior sell emphatically well. It is hard to envision the social breakdown Bell fears, or indeed any effective cultural challenge to a market system that systematically incorporates protest.

Keywords: Capitalism; Consumer Culture; Daniel Bell; Max Weber

When the Protestant ethic was sundered from bourgeois society, only the hedonism remained, and the capitalist system lost its transcendental ethic. (Daniel Bell, 1976, p. 21)

When Daniel Bell's The Cultural Contradictions of Capitalism was published 30 years ago, the book was a quick best-seller and soon eclipsed earlier studies of the American culture of self-fulfillment - notably David Riesman's (1950) and Philip Rieff's (1966), who were Bell's onetime colleagues at the College of the University of Chicago. The book remains the entry point to the rich literature on the history and sociology of consumer gratification produced since, by Warren Susman, T.J. Jackson Lears, Christopher Lasch, Richard Sennett, William Leach, and, more recently, Lawrence Glickman and Axel Honneth. Cultural Contradictions endures as the default citation on the "hip-drug-rock culture," as Bell termed it, especially in the public intellectual arena.

Jefferson Pooley is Assistant Professor of Media and Communication at Muhlenberg College. Correspondence to: Muhlenberg College, 2400 Chew Street, Allentown, PA 18104, USA. Email: pooley@muhlenberg.edu 
This is too bad, if only because Bell's book has helped to occlude the hedonism at the core of the market economy. The book gets it wrong: There is no real contradiction, after all, between capitalism and its culture.

\section{Max Weber on Modernity}

Many accounts of modern decline can be placed under the heading of one or both of Max Weber's great theses concerning modernity. That is, the two tragic (and related) "losses" identified by Weber as the inevitable progeny of the modern rationality - the twin losses of freedom and meaning-provide a useful way to classify other declinists.

On the one hand, it is possible to identify a group of thinkers preoccupied with the "iron cage" - with instrumental rationality and its institutional accomplices in the economy and government. One thinks of the technological doomsdayism of Jacques Ellul or the "totally administered world" of Adorno and Horkheimer, and indeed much of the chastened Marxism of the post-1917 West, robbed as it was of Marx's optimistic telos. Here the concern is with the stifling grip of modern institutions.

Many others, though, emphasize Weber's second thesis concerning the world's disenchantment. For them, rationality and the Enlightenment project are faulted for corroding a coherent cosmic order or else some heroic dimension crucial to human flourishing. In place of these, modernity substitutes excessive freedom, individualism, and relativism - the agonizing indeterminacy of the "warring gods." Tocqueville, Nietzsche, much Romantic thought, and even recent communitarian laments subscribe to this thesis in some form.

Daniel Bell, American sociologist and author of many influential books including The End of Ideology (1960) and The Coming of Post-Industrial Society (1973), can be safely located within this second cluster. His Cultural Contradictions of Capitalism (1976) is essentially an extended meditation on Weber's loss of meaning claim. Bell's argument is that capitalism, in its infancy, was originally tied to a legitimating culture and character structure, that of the bourgeois and his ethic of self-restraint. In its birth, however, this original coherence concealed the instrument of its own death; as modernity unfolded, he argues, a complex interplay of three elements-bourgeois self-understanding, Modernism, and capitalism-produced fundamental contradictions, with Modernist culture and certain tendencies in capitalism both undermining bourgeois self-discipline. A culture of hedonism and depthless relativism came to clash with - and, to a degree, replaced - the previous ethic of delayed gratification.

Bell worries about these trends for two reasons. He argues, first, that this culture of self-absorption appears unable to provide the resources necessary to craft a meaningful life. But he also contends that the contradictions produced by modernity ultimately foster instability; this new incoherence, he insists, renders legitimation and social order very difficult to maintain. Both of these claims, it seems to me, are open to challenge. 


\section{Bell's Problem of Order}

Weber paints a bleak picture of modernity, forced as he is to confront the Nietzschean denuding of metaphysics and the rise of state capitalism. As noted, he contends that Western rationalization results in two distinct losses. Meaning-dependent humans, he argues in his first thesis, formed religions to explain the world's injustice and suffering. The rationality of theodicy, though, folded upon itself: its demands for consistency and intellectualization eventually stripped away the meaningful certainty of religious worldviews, leading to the "disenchantment of the world." Bereft of metaphysical certitude but nevertheless fundamentally dependent on meaning, humanity is thrust into an agonizing polytheism, where "different gods struggle with one another, now and for all times to come" (1918/1946, p. 148).

Weber connects his disenchantment thesis to his arguments concerning modernity's “iron cage." In The Protestant Ethic and the Spirit of Capitalism (1905/1958), he sets out to explain why this awesome economic system took root in the West first. His answer, was that: Puritanism's "this-worldly asceticism," its emphasis on a calling, and, more narrowly, the Calvinist tenet of predestination, together fostered a set of moral ideals hospitable to capital accumulation - the key to a capitalist economy and absent from traditional economic systems.

However, Weber argues, the inevitable charismatic entropy dissolved away this original motivating force of frugality and self-restraint, hardening the economy into a self-perpetuating machine of instrumental rationality - a "mechanized petrification, embellished with a sort of convulsive self-importance" (p. 182). The idea of "duty in one's calling," he reveals in the haunting close of the book, "prowls about in our lives like the ghost of dead religious belief" (p. 182). The tragedy of the modern economy is that the "Puritans wanted to work in a calling," while "we are forced to do so" (p. 181).

Along a parallel and related track, politics was transformed by its own charismatic intervention. The separation of office and office-holder in the eighteenth century, coupled with a new ethic of dedicated public service, led to the rise of rule-bound and formally meritocratic bureaucracies. As with the Protestant ethic, the initial charismatic jolt - the spirit of diligent service to a public calling - dissipated as it became routinized; the "original storm" suffered a "slow death by suffocation" (Weber 1914/1978, p. 1120). As the charismatic impulse withered away in both politics and economics, increasingly efficient and rationalized capitalism and bureaucracy trapped people in the infamous "iron cage." The "routines of everyday life" leave the "old gods" disenchanted, and return to confront people in the "form of impersonal forces” (Weber 1918/1946, p. 149).

Bell's selective reception of Weber's arguments - particularly those found in The Protestant Ethic - reveals a great deal about his (Bell's) diagnosis of modernity. For Weber, the routinization of the Protestant ethic, as well as the newfound legitimacy of rational-legal bureaucratic authority, constricts freedom in a ruthlessly effective manner. Although we can only imagine these institutions arising in the context of a disenchanted world-and to that extent their emergence is linked to the loss of 
meaning - the point for Weber is that it is difficult to imagine any sustained challenge to the iron cage's ability to reproduce and legitimate itself.

For Bell, there seems to be an altogether different reason to lament the routinization of the Protestant ethic. It is this ethic - and, to be sure, religiosity itself - that lends life under capitalism its meaning and its coherence. And this ethic of self-restraint also provides the cohesive and legitimizing force that holds society together. In contrast to Weber, who stresses near-absolute control, Bell argues that the erosion of this value system leads to fragmentation, breakdown, and instability. It's not that the routinization of the Protestant ethic traps us in a cage; we need to worry about it because it frees us from a cage of sorts - the set of meanings and limits that bind us together as a society. Bell, in short, is concerned with the problem of order, a problem that seems utterly alien within Weber's framework.

It is one of the strengths of Bell's approach that he adopts, following Weber on this point, a multidimensional approach to the question of causation and explanation in social change. (Weber's Protestant Ethic was meant, in part, as a shot across the bow of orthodox Marxists.) Bell insists, in contrast to reductionist approaches to sociology's "structure-culture" problematic, that neither the social structure nor the culture ultimately determines the other. He agrees with Weber that ideas are the switchmen on the tracks of history, which is not to deny that social structure can in turn impact the culture.

\section{The Culture Contradictions of Capitalism}

"In early modern times," writes Bell in Cultural Contradictions, "bourgeois culture and bourgeois social structure fused a distinct unity with a specific character structure around the theme of order and work" (p. 36). Infant capitalism and the culture of selfrestraint were interwoven and sustained one another. Bell suggests that this sort of consistency is a necessary precondition for social stability. "Historically," he insists, "most cultures and social structures have exhibited unity, although there have always been small groups expressing esoteric, deviant, usually libertine values" (p. 36).

But not so for the modern West: This original coherence eventually crumbled under the weight of contradictions whose source, in a familiar pattern, could be traced to the very ideals that first shaped the new capitalist order. In this, as in many aspects of his argument, Bell (fittingly perhaps) contradicts himself. Sometimes he suggests that the capitalist economy and the culture derived from a common source, "the ideas of liberty and liberation," leading both eventually to challenge the bourgeois character structure (1979, p. xxiii). In this vein, he contends that Protestantism is inherently "anti-institutional and antinomian," so that even if it encourages self-denial in the short run, it plants the long-run seeds of its own demise (p. 286). At other points in his argument, though, he claims the tension derives from bourgeois society's "double source": its Puritan character, on the one hand, and a "secular Hobbesianism" of radical, unrestrained individualism, on the other (p. 79).

Whatever the source, Bell advances his thesis of internal instability on two tracks: the bourgeois character structure of self-restraint is undermined both by Modernism 
and by certain tendencies within capitalism itself. The two arguments are related, of course, but in Bell's telling, at least, they coexist somewhat awkwardly. (Reading him, one can't escape the impression that his writing style resembles a machine-gun burst: He issues grand theses in rapid succession, and they all seem to land in slightly different spots. As Laurence Veysey once remarked, for Bell "too many things turn out to be primary" [1982, p. 53].) Hence the strange inconsistency in this book, in which some passages blame everything on Modernism, while others hold the acquisitive impulse in capitalism responsible.

On balance, though, he reserves the bulk of his scorn for Modernism as an artistic movement. "The discussion of Modernism is the inner thread of this book, for I see Modernism as the agency for the dissolution of the bourgeois world view and, in the past half-century, as gaining hegemony in culture" (1979, p. xxi). With its elevation of the aesthetic over moral norms, its valorization of the new, and its obsession with the self, Modernist art and literature effect a "rage against bourgeois orderliness" (p. xxi). The experimental and antinomian impulses of the Modernist avant-garde - as expressed in its rejection of the ordered framework of bourgeois space and time, its repudiation of mimesis, and its preoccupation with the form or medium itselfcontemptuously reject the very character structure that has done the most work in maintaining social order. It is important to note that Bell occasionally widens his critique beyond Modernism, although he never specifies how these other currents fit into his thesis. He points, for example, to the "Young Intellectuals" of the early 1900s - including Walter Lippmann, John Reed, Van Wyck Brooks, and Harold Stearns - and their demands for instinctual self-expression, as well as their flirtation with European philosophical irrationalism. He also, although only in passing, faults political liberalism for joining the assault on bourgeois self-restraint.

Bell contends that the roots of Modernism can be traced, in part, to the psychic ramifications of rapid social change in the nineteenth century. The increase in mobility, the growth of cities and the break-down of small-town life, the disorientation of sense impression in space and time, the openness to the new at the expense of the traditional - the transition, in short, from Gemeinschaft and Gesellschaft - cultivated the impulse to shock in Modernism. The artistic drive was also fueled by the related decline of religious certitude in increasingly secular societies. In combination, Bell argues, the disorientation of social change and secularization gave birth to Modernism, as this movement in art and literature "took over the relation with the demonic." But instead of taming it, as religion tried to do, the "secular culture ... began to accept it, explore it, and revel in it, coming to see it as a source of creativity" (p. 19).

Thus even if its genesis can be traced to other cultural and social conditions, Modernism, once born, thrived with its own autonomous and self-sustaining logic. It has become, Bell claims, the "most dynamic component of our civilization, outreaching the dynamism of technology itself" (p. 34). In the last fifty years especially, he argues, culture has "taken the initiative in promoting change," yoking the economy to its erratic trajectory (1979, p. xxv). Even though Modernism by the 1970s had become "exhausted," its influence lived on in the "cultural mass"-Bell's term for the producers of popular culture. So Modernism, once restricted to a narrow 
avant-garde, seeped into the lived reality of the population. "The central point is that - at first, for the advanced social groups, the intelligentsia and the educated social classes, and later for the middle class itself-the legitimations of social behavior passed from religion to modernist culture" ( $\mathrm{p}$. xxiv). With open disdain, he rejects the 1960s counter-culture and its self-described novelty; Woodstock and the Haight, he implies, are merely the last mile of Modernism's long march.

But, as discussed above, for all the vitriol he spills over Modernism, Bell occasionally holds certain inherent leanings in capitalism responsible for the breakdown of the Protestant ethic. With considerable self-contradiction, he asserts that the unfolding of capitalism "destroyed the keystone of that character" with its acquisitive impulse (p. 295), that "the Protestant ethic was undermined not by modernism but by capitalism itself" (p. 21), and that the erosion of self-restraint owed "as much to changes in social structure as to changes in the culture" (p. 55).

In a subtle but important variation on Weber's thesis, Bell, drawing on Werner Sombart, identifies two key sources of capitalism: the asceticism emphasized by Weber, but also a fundamental acquisitiveness. As capitalism matured, the acquisitive impulse vanquished its ascetic counterpart, and "with it one kind of moral legitimation of capitalist behavior" (1979, p. xx). "What became distinctive about capitalism - its very dynamic - was its boundlessness," he argues. "No limits. Nothing was sacred. Change became the norm. By the middle of the nineteenth century, this was the trajectory of the economic impulse" (p. $x x$ ).

The acquisitive tendency reached its purest form with the growth of the consumer economy from the 1920s. He reserves special scorn for the invention of the installment plan, the "greatest single engine in the destruction of the Protestant ethic" (p. 21). The growth of mass media and the emergence of advertising and its strategy of demand stimulation fueled the new hedonism. Even though the ethos of work and delayed gratification lives on inside corporations, the logic of their production encourages the "voluptuous gratification of the lineaments of desire." The result, he concludes, is that a company finds its employees "straight by day and swingers by night" (1979, p. xxv).

Whatever the relative weight Bell assigns to capitalism's primordial acquisitive impulse, on the one hand, or Modernism's antinomian zeal, on the other, he's clear about his claim that modern Western societies have embraced a destructive hedonism.

In this double contradiction, what has been established in the last thirty years has been the tawdry rule of fad and fashion: of "multiples" for the culturati, hedonism for the middle classes, and pornotopia for the masses. And in the very nature of fashion, it has trivialized the culture. (1979, p. xxvii)

The growth of crime, divorce rates, inner-city decay, and out-of-wedlock births are a few of the products of society's "official, ceaseless search for a new sensibility" (p. 34).

The point for Bell is not that this culture of self-affirmation has thoroughly transformed society; the title of the book, after all, refers to the West's contradictions. The stress, rather, is on the breakdown of the original coherence of culture, economy, and character structure, and its replacement with two contradictions. The first is the "radical distinction" between the social structure - which "remains bourgeois" and is 
directed by efficiency, functional rationality, and the archaic remnants of the Protestant ethic - and the culture, which is "prodigal, promiscuous, dominated by an antirational, anti-intellectual temper" (p. 36). There is also, he admits, a second contradiction, this one internal to the social structure:

On the one hand, the business corporation wants an individual to work hard, pursue a career, accept delayed gratification - to be, in a crude sense, an organization man. And yet, in its products and its advertisements, the corporation promotes pleasure, instant joy, relaxing and letting go. (p. 70)

Bell, as I claimed earlier, considers these trends toward narcissism and contradiction troubling for at least two different though related reasons, one centered on the possibility of crafting a meaningful life, and the other concerned with social stability. These two laments are linked in that religion and the Protestant ethic provided resources for both. "The real problem of modernity," Bell famously asserts, "is the problem of belief. To use an unfashionable term, it is a spiritual crisis, since the new anchorages have proved illusory and the old ones have become submerged" (p. 28).

With the breakdown of coherent belief systems and religious certainty, and their replacement with contradiction and "warring gods," it is near impossible, he claims, to sustain a meaningful identity. Religion and the binding of capitalism with the Protestant mindset provided the necessary moral horizon with which to shape a life worth living. It is interesting to note that, in contrast to others like Tocqueville, Bell regards the early coherence of the bourgeois order as a plausible background horizon of this sort, and not an immediate source of its breakdown. The shallow, self-indulgent consumerism of our societies displaces all "transtemporal conceptions of reality" like religion with a depthless focus on the present. Although we cling to the momentary frenzy of the Dionysian act, this "intoxication always passes, and there is the cold morning after, which arrives inexorably with the break of day" (p. 50). Ultimately, Modernism's "sympathy for the abyss" and the ever-present new leads to a sort of debilitating nihilism. "[W] hen one is cut off from the past, one cannot escape the final sense of nothingness that the future then holds" (p. 50). It is only religion and its roots in the past that permit us to cope with these existential predicaments.

Bell's second lament, as I have claimed, concerns the breakdown of social order. Like many other social theorists, he is preoccupied with what Talcott Parsons (1937) called the "Hobbesian Question," sometimes referred to as the "problem of order": Why isn't society a "war of all against all"? How is a stable society possible at all? Bell's version: "What, then, can hold the society together?" (p. 84). The original coherence of capitalism, along with its religious sanction, lent it a "transcendental justification." But the erosion of that ethic has left Western societies without a strong legitimation, thereby undermining the foundations of capitalism. "The sociological truism," he argues, "is that a societal order is shored up by its legitimations, which provide the defenses against its despisers" (1979, p. xxvii). But now, as we have seen, culture has abandoned this legitimizing role in favor of self-gratification. "It is a prescription," he worries, "for the dissolution of a shared moral order" (p. xxvii). He holds up the self-indulgence of the late Roman empire as a historical warning. 
What, does he argue, is to be done? It is true that he agrees with Edmund Burke (1790), John Gray (1995), and others that the Enlightenment contains the seeds of its own instability and delegitimation, but in many ways he's far less fatalistic than Gray. In fact, his solution to both problems - crafting a meaningful life and maintaining social order - is a return to religion and moral limits. He somewhat mysteriously clings to the hope that religion might be reborn, so as to "restore the continuity of generations," although he admits this new faith cannot be manufactured. (Consider, by contrast, the deeply pessimistic last few paragraphs of Weber's 1918/1946 “Science as a Vocation.") And he observes signs that the long era of Modernist narcissism is "coming to a slow close" (1979, p. xxix). He seems to imply, moreover, that there is some kind of functional necessity for moral cohesiveness, and that at any rate the history of Western society has always been a "dialectic of release and restraint" (p. 19).

\section{Capitalism and its Culture}

How should we respond to Bell's theses? Bell's first lament, that modernity renders a meaningful life unattainable, is answered with consider force in Charles Taylor's (1989) magisterial Sources of the Self (and, in briefer form, his 1992 Ethics of Authenticity). His argument is that, however debased, there is a moral ideal behind the prevailing culture of self-fulfillment that is worth recovering.

As for Bell's second lament - the fear that, bereft of its legitimation, capitalist society might unravel - I want to respond by highlighting the deeply symbiotic relations between the market and the pop culture he decries. There is an historical irony here: Although they approach the question with opposed diagnoses - one hopeful, the other chastened-both Bell and Marx claim that some set of internal contradictions in capitalism will lead to the system's breakdown. Of course, the rate of profit didn't fall and the working classes weren't immiserated; neither has capitalism suffered from a crisis of legitimacy. Neoliberal triumphalists and the defeated Marxists of the post-1917 West, by contrast, both appreciate the awesome staying power of "Energizer Bunny" capitalism - its uncanny ability to reproduce itself. The credit card and the bikini do not, in the end, threaten the market's legitimacy.

Bell nevertheless insists that the "hip-drug-rock culture" undermines the "social structure itself by striking at the motivational and psychic-reward system which has sustained it" (p. 54). The one emphasizes instrumental rationality and meritocratic advance; the other promotes "apocalyptic moods and anti-rational modes of behavior" (p. 84). Their clash, he asserts with his own cataclysmic flourish, is the "historical cultural crisis of all Western bourgeois society" (p. 84).

But there is no such crisis, and it is hard to imagine one. Dionysus, after all, is welcomed with enthusiasm into the boardroom, mainly because apocalyptic moods and anti-rational modes of behavior sell emphatically well. Indeed, it is possible to argue, without claiming that one is derived from the other, that the popular culture corresponds to the underlying logic of capitalism, in which, as Marx and Schumpeter observed in their own way, "all that is solid melts into air" under the impact of "gales of creative destruction." Modernism, especially in its diluted, popular form, is wind 
to the market's fire - and certainly not the "avowed enemy" of the "ruling class" (Bell, 1979, p. xxiii).

There's very little contradiction, then, between the rational, profit-seeking corporation and the popular culture it helps sell. As reported in a recent Frontline documentary (“American Porn"), a number of Fortune 500 giants like AT\&T and General Motors are aggressively entering the lucrative pornography business; Fox touts one of its new shows with the promise, "Network television has never gone this far!" Regardless of the sources of consumer capitalism and the hedonist popular culture - even if we admit that these are varied and partially derived from moral ideals - it seems difficult to deny that there is at least an "elective affinity," to use Weber's phrase, between the two. There is not too much, to state the point flippantly, that separates Jerry and Robert Rubin.

While there is some logic to Bell's worry that carefree iconoclasm will undermine America's fanatical work ethic - the swinger-by-night argument - the country's tolerance for sustained toil is apparently limitless, as long as the current, cubicled "free agent" can be successfully contrasted to his stuffy, gray-flanneled predecessor. It is true that few employees define themselves according to the sober, prudential Protestant ethic in today's workplace, now replete with pool tables and dress-down Fridays. But it is also undeniable that Americans are working harder than ever, as Juliet Schor (1991) has documented in The Overworked American. The result is that the "organization man" label now exists merely as a caricature with which to contrast Tom Peters-style "The Rules are Changing!" advertising - even as current workers punch the clock more religiously.

If nothing else, capitalism's fondness for melting solids into air casts doubt upon America's peculiar political spectrum, where traditionalists make common cause with free-market zealots, and both share the label "conservative." Leftists, for their part, decry the market's excesses and simultaneously embrace the permissive counterculture - the fuel of the consumer economy. It doesn't seem too surprising, then, that the left "won" culture while the right "won" economics over the last fifty years. In fact, it may be that the right won economics because the left won culture.

Consider Modernism and the counterculture, which Bell curiously labels enemies of the market. It is obvious that capitalism adopted most of the symbols of 1960s protest - so that yesterday's street chant is today's Toyota ad-but not because of some conspiracy theory of the "executive committee" stripe. The market rides these waves of dissent because restless innovation and the great refusal, properly filtered, bolster the bottom line. The logic of capitalism, in short, mirrors the logic of Modernism, even if one cannot be reduced to the other. This is the point stressed by Thomas Frank (1997a,b, 2000) in his hilarious and sobering send-ups of "liberation marketing," in which Che is used to sell soda. It is hard to envision the social breakdown Bell fears, or indeed any effective cultural challenge to a market system that systematically incorporates protest.

I want to stress a final and related point. Bell claims that the abandonment of the Protestant ethic leaves capitalism with "no moral or transcendental ethic" (p. 70). To some extent, as I have argued above, this does not matter much; the market does not 
need one to go on reproducing itself. But it is also true that the market is taken to be its own justification, especially in Anglo-Saxon cultures. The market, in other words, is frequently held up as a moral ideal bearing unique democratic legitimacy, vanquishing elitism and government waste. This holds also at the level of consumption, where the animating, expressive tools used to construct an identity are increasingly drawn from brands.

But we don't have to accept the defeatist pathos of the Marxists or the nauseating applause of CEOs and the Heritage Foundation. Indeed, I hope that we can say that the untrammeled market and the hedonistic popular culture ought to be challenged in some way, and that perhaps we might find such resources immanent to the culture itself. But it seems safe to conclude, at least, that Bell need not worry about capitalism's impending self-destruction.

\section{References}

Bell, D. (1960). The end of ideology: On the exhaustion of political ideas in the Fifties Glencoe, IL: Free Press.

Bell, D. (1973). The coming of post-industrial society: A venture in social forecasting New York: Basic Books.

Bell, D. (1976). The cultural contradictions of capitalism New York: Basic Books.

Bell, D. (1979). Foreword. In The cultural contradictions of capitalism (2nd ed., pp. xi-xxxii). London: Heinemann.

Burke, E. (1790). Reflections on the revolution in France London: J. Dodsley.

Frank, T. (1997a). The conquest of cool: Business culture, counterculture, and the rise of hip consumerism Chicago: University of Chicago Press.

Frank, T. (1997b). Why Johnny can't dissent. In T. Frank \& M. Weiland (Eds.), Commodify your dissent: Salvos from The Baffler (pp. 31-45). New York: Norton.

Frank, T. (2000). One market under God: Extreme capitalism, market populism, and the end of economic democracy. New York: Doubleday.

Gray, J. (1995). Enlightenment's wake: Politics and culture at the close of the modern age. London: Routledge.

Kirk, M. (Director). (2002). American Porn. (Documentary). United States: Frontline.

Parsons, T. (1937). The structure of social action New York: McGraw-Hill.

Rieff, P. (1966). The triumph of the therapeutic: Uses of faith after Freud. London: Chatto \& Windus.

Riesman, D. (1950). The lonely crowd: A study of the changing American character. New Haven, CT: Yale University Press.

Schor, J. (1991). The overworked American: The unexpected decline of leisure. New York: Basic Books.

Taylor, C. (1989). Sources of the self: The making of the modern identity. Cambridge, MA: Harvard University Press.

Taylor, C. (1992). The ethics of authenticity. Cambridge, MA: Harvard University Press.

Veysey, L. (1982). A postmortem on Daniel Bell's postindustrialism. American Quarterly, 34, 49-69.

Weber, M. (1946). Science as a vocation. In H. H. Gerth \& C. W. Mills (Eds.), From Max Weber: Essays in sociology (pp. 129-156). New York: Oxford University Press. (Original work published 1918).

Weber, M. (1958). The Protestant ethic and the spirit of capitalism. New York: Scribner. (Original work published 1905)

Weber, M. (1978). Economy and society: An outline of interpretive sociology. Berkeley: University of California Press. (Original work published 1914) 